DOI https://doi.org/10.30525/978-9934-26-180-0-38

\title{
PROBLEMS OF INTERCULTURAL COMMUNICATION IN THE FIELD OF MODERN TRANSLATION
}

\author{
Karachova D. V. \\ Candidate of Philological Sciences, \\ Associate Professor at the Department \\ of Business Foreign Language and Translation \\ National Technical University «Kharkiv Polytechnic Institute» \\ Myroshnychenko V. M. \\ Candidate of Philological Sciences, Associate professor \\ Associate Professor at the Department \\ of Business Foreign Language and Translation \\ National Technical University «Kharkiv Polytechnic Institute» \\ Ahibalova T. M. \\ Candidate of Philological Sciences, \\ Associate Professor at the Department \\ of Business Foreign Language and Translation \\ National Technical University "Kharkiv Polytechnic Institute» \\ Kharkiv, Ukraine
}

Our modern world is an extremely developed and multinational unity. No country or nation can exist apart from other nations nowadays. The relevance of this topic is confirmed by the fact that intercultural relations and cooperation are extremely important for any country these days because political and economic relations between different countries are extremely important and are in great demand nowadays, it is not even possible to imagine modern societies without productive cooperation. According to Shakirova D.T. Western scientists figuratively depict culture in the form of an iceberg, which is based on cultural values and norms, and its top is individual human behavior, based on those values and norms and manifested primarily in communication with other people. Linguists Vereshchagin E.M. and Kostomarov V.G. admit that "no culture exists in isolation. In the course of its life, it is forced to constant turn either to its past or to the experience of other cultures. This appeal to other cultures and is called "cultural interaction" [1, p. 25]. Shakirova D.T. claims that intercultural communication is communication between representatives of different cultures, which involves both direct contacts between people and their 144 
communities, and indirect forms of communication (including writing, electronic communication and so on). Gudkov D.B. defines intercultural communication as "communication of linguistic individuals belonging to different linguacultural communities" [2, p. 51]. It is necessary to admit that intercultural communication is a vigorously developing scientific direction that is in demand by society nowadays. It exists at the intersection of linguistics, cultural and communication studies.

Modern field of Philology also cannot ignore the topic of intercultural communication because, for example, the field of translation works extremely closely with the cultures of different nations. Consider in more detail.

Simultaneous interpretation requires an interpreter to have a significant knowledge base not only in the field of translation, but also in the field of cultural awareness of the nations he/she works with, as lack of basic knowledge can lead to a conflict and a refusal to cooperate. Each nation is characterized by certain features and specifics of behavior. The interpreter should monitor not only the authenticity of the translation, but also the requirements of dress code, neatness and awareness of the rules of conduct. Therefore, it is so important for the future interpreters to learn the basic norms of behavior and cultural features of different countries of Europe, Asia, etc. in classes on theory and practice of translation.

Furthermore, it is very important to admit that one of the most significant factors of cultures can be considered their belonging to individualistic or collectivist culture. It is the factor that radically distinguishes the cultural features of the West and the East. In societies of the individualistic type, people act primarily on the basis of personal interests. Respect for human rights and the great value of human life can be considered the basic values of individualistic societies. In individualistic cultures the individual always comes first.

On the contrary, collectivist societies have a system of values in which people perceive themselves as part of a social or working group, and the interests of the individual are pushed to the background. From the moment of his/her birth, each person is included in a certain community (a family, which includes distant relatives, some groups, etc.), adheres to the interests of his/her particular group and does not show his/her views or preferences, different from those shared by all members of the group.

Now let's take a closer look to the main specific features of individualistic and collectivist societies.

According to the classification by Myasoedov S.P. [3]:

Countries with an individualistic approach can be mainly characterized by:

1. General presence of criticism of colleagues and subordinates (a single employee). 
2. Promotion is associated solely with the merits of the person and the results of his/her activities.

3. The management system is focused on the individual, not the group.

4. Everyone focuses on personal success.

Countries with a collectivist approach can be mainly characterized by:

1. The presence of criticism of a group of subordinates, or the team as a whole, but not a single employee.

2. The management system is focused on the team or group of people, but not a single employee.

3. Each worker is focused on achieving the success of the team, not his personal.

4. Strict hierarchical system in companies.

With all these important factors in mind, the interpreter must be extremely careful and diligent in his/her work and avoid misunderstandings and conflict situations, as respect for colleagues belonging to other cultures and nations must always be present. According to Ter-Minasova, the three concepts of "patience", "tolerance", "respect" are a universal formula for successful intercultural communication [4, p. 138], which should always be remembered.

Ukrainian interpreters belong to the type of individualistic society, so they must pay a lot of attention to the cultural aspect of work with other nationalities because intercultural misunderstandings can lead to different problematic situations and conflicts.

Cooperation with Asian partners is gaining more and more popularity each year, so interpreters should always be aware of all the intricacies of the partner country's diplomatic and cultural backgrounds. Also, we shouldn't forget that very often the interpreter is responsible for the impression that partners will receive after negotiations because if a head of the company or a politician is not very competent in his/her work, so all the responsibility for the accuracy of information received by partners rests with the interpreter and his/her professionalism, so nowadays this topic is extremely relevant.

\section{References:}

1. Верещагин Е.М., Костомаров В.Г. Язык и культура. Москва, 1990. $246 \mathrm{c}$.

2. Гудков Д.Б. Теория и практика межкультурной коммуникации. Москва, 2003. 288 с.

3. Мясоєдов С.П. Крос культурний менеджмент [URL: https:// stud.com.ua/79805/menedzhment/kross-kulturnyy_menedzhment (дата звернення 21.12.21)] 
4. Тер-Минасова С.Г. Язык и межкультурная коммуникация. Москва, 2000. 259 с.

5. Шакирова Д. Т. Актуальные проблемы межкультурной коммуникации [URL: https://articlekz.com/article/23819 (дата звернення 21.12.21)]

DOI https://doi.org/10.30525/978-9934-26-180-0-39

\title{
THE MAIN CHARACTERISTICS OF THE LANGUAGE CLICHÉ IN THE TEXT OF THE PATENT
}

\author{
Ponomarenko O. O. \\ Candidate of Philological Sciences, \\ Senior Lecturer at the Translation Department \\ Kremenchuk Mykhailo Ostrohradskyi National University \\ Artemenko Yu. O. \\ Candidate of Philological Sciences, \\ Associate Professor at the Translation Department \\ Kremenchuk Mykhailo Ostrohradskyi National University \\ Shulzhenko Yu. M. \\ Senior Lecturer at the Translation Department \\ Kremenchuk Mykhailo Ostrohradskyi National University \\ Kremenchuk, Poltava region, Ukraine
}

Linguistic and translation studies explore and describe the stylistic features of the textual form of patents, emphasizing the stylistic heterogeneity of these textual forms through a combination of characteristics of scientific and technical texts. In addition, special attention is paid to a clearly structured form of presentation of information, where each structural part has a specific communicative purpose.

Pre-translation analysis of clichés in the texts of the patent primarily serves the fact that all patents are built on a standardized structure. Each part of this structure corresponds to a specific communicative purpose, so it should contain language units that present information, that gradually and logically describe the invention. It should be noted that the informative and necessary nature of clichés is manifested in the fact that they provide rapid creation of the text, speed up and simplify its reading and understanding. [2, p. 95]. 